\title{
K OTÁZKE ETICKÝCH KOMPETENCIÍ V PROFESIJNEJ ETIKE MANAŽÉRA
}

\section{Daniela Navrátilová}

\section{Kl'účové slová}

Manažér - profesia - kompetencie - morálne postoje - etika

\section{Key words}

Manager - profession - competencies - moral attitudes - ethics

\begin{abstract}
Abstrakt
V článku je venovaná pozornost' úlohe manažérskej etiky pri formovaní etických kompetencií ako dôležitej stránky profesionálnej prípravy manažéra. Autorka chápe tento proces ako otvorený a neukončený, ktorý sa stáva súčast'ou intelektuálnej výbavy manažéra s požiadavkou jeho tvorivej implementácie.
\end{abstract}

\begin{abstract}
The article deals with the role of managerial ethics in the process of ethical competencies formation as important part of professional training of a manager. The author understands the process as open and continuous being integrated to intellectual equipment of a manager with the aim of its creative implementation.
\end{abstract}

\section{Úvod}

V príprave budúcich manažérov by sa mali odrážat' základné tendencie súčasných spoločensko-ekonomických procesov, ktorých podstatnou črtou súčasnosti je okrem prekonávania hospodárskej krízy predovšetkým globalizácia ako komplexné prerastanie spoločenských procesov (ekonomických, sociálnych, právnych, kultúrnych) navzájom. Táto príprava samozrejme odráža aj prebiehajúce integračné procesy, ktorých zosobnením je používanie termínu „euromanažér“, ktorý v sebe zahŕňa aj neoddelitel'nú etickú dimenziu tohto povolania v podobe manažérskej etiky. Na zdôrazenie významu tejto etickej dimenzie profesionálnej prípravy manažéra autorka používa pojem „etické kompetencie manažéra“, ktorý sa v literatúre nepoužíva. Autorka ho zavádza na základe svojich doterajších skúseností výučby manažérskej etiky a chce ním podčiarknut' práve prepojenie na túto aplikovanú etiku ako systém teoretických poznatkov, ktorý profesijne rozvíja morálny rozmer osobnosti manažéra.

Samotný pojem „kompetencie“ podl'a slovníkovej definície znamená oprávnenie vykonávat’ určitú činnost'. Vo vzt’ahu k vzdelávaciemu procesu a odbornej príprave manažérov vychádzame z európskych dokumentov, medzi ktoré patrí napríklad „Implementácia Lisabonského programu spoločenstva“ z roku 2006, ktorá podčiarkuje úlohu kl’účových a generických kompetencií pri rozvíjaní predovšetkým podnikatel'ských zručností pre uplatnenie sa na pracovnom trhu. V tomto európskom kontexte sa kladie dôraz na rozvoj kompetencií nad rámec odbornej prípravy, odborných vedomostí a zručností. K takémuto typu kompetencií podl'a autorky neodškriepitel'ne patria aj etické kompetencie, ktorých obsah úzko súvisí s etickými princípmi riadenia a podnikania. 


\section{Manažér a etika}

Manažérska etika ako profesijná etika manažéra je širší pojem ako jednoduché dodržiavanie morálnych zásad v riadení a rozhodovaní manažéra. Ide predovšetkým o tvorivé a proetické myslenie, ktoré znamená schopnost' manažéra konfrontovat' svoje úvahy a postoje k riadeniu na základe svojho vzt’ahu k morálke a svojich osobných predpokladov [Dytrt 2006, s. 3]. Manažérska etika ako súčast' vízie moderného manažmentu sa preto v súčasnosti musí venovat' aj rozvíjaniu etických kompetencií manažéra ako súčasti jeho odbornej prípravy. Táto požiadavka súvisí so zmenou pohl'adu na podnikanie na začiatku 21. storočia, ktorý podčiarkuje skutočnost', že povest' firmy sa stáva konkurenčnou výhodou, čo znamená, že firmy okrem dosahovania efektivity podnikania musia aktívne prihliadat' aj na záujmy strán, ktorých firma ovplyvňuje - teda od firmy sa požaduje byt' sociálne zodpovednou organizáciou. Európska únia presadzuje model corporate social responsibility (podnikovej sociálnej zodpovednosti) a vyvíja aktivity na zlepšenie sociálne zodpovedného konania. Ide o prístup, v rámci ktorého firma pri svojom rozhodovaní berie do úvahy vplyv svojho konania na širšiu komunitu a spoločnost'. Toto tzv. firemné občianstvo (corporate citizenschip) zahŕňa pomerne široký koncept, ktorý popri podnikatel'skej a manažérskej etike sa dotýka aj d'alších oblastí, ako napr. ochrana l'udských práv a ochrana životného prostredia.

V súvislosti s týmito trendami prebiehajú vývojové zmeny aj v samotnom chápaní (teórii aj praxi) manažmentu. Progresívne trendy v 21. storočí sa orientujú predovšetkým na budovanie kultúry organizácie (corporate culture). Ide o plnenie nových a náročných úloh, ktoré súvisí s kreativitou ako neoddelitel'nou dispozíciou manažérov pri dosahovaní a udržaní dobrého mena firmy. A tu má svoje nezastupitel’né miesto aj etické vzdelávanie manažéra.

Problémom etiky v rovine etických kompetencií v profesii manažéra venujú vel'kú pozornost' francúzski autori, ktorí sú u nás menej známi. Francúzska odborná literatúra analyzuje túto problematiku $\mathrm{v}$ rôznych súvislostiach. Všeobecne predovšetkým $\mathrm{v}$ rámci etiky $\mathrm{v}$ podniku (l'éthique de l'entreprise alebo l'éthique des affaires). Zároveň sa stretneme s touto problematikou aj pod názvom etika riadenia podniku (l'éthique dans la question de l’entreprise). Ethique managérial je zriedkavejšie sa vyskytujúci pojem, ale etika je považovaná aj za podstatnú manažérsku kompetenciu a analyzuje sa všeobecne v súvislosti s problémom vzt’ahu etiky a manažmentu.

Ako ilustráciu uvedieme publikáciu autorov Pesqueux, Y. a Biefnot, Y. L'éthique des affaires. Management par les valeurs et responsabilité sociale (2002), ktorá je široko koncipovaná. Manažérsku etiku chápu autori tejto publikácie ako novú disciplínu v rámci teórie riadenia a zároveň ako aplikovanú etiku [tamže XIII]. Zdôrazňujú predovšetkým aktuálnu potrebu zjednotenia teoretického prístupu obsiahnutého v rovine filozoficko-etickej a praktického prístupu, ktorý sa odráža $\mathrm{v}$ širších sociálnych kontextoch tejto problematiky a vytvára nové perspektívy prístupu k riadeniu. Upozorňujú pritom tiež na to, že nie je možné v rámci vzdelávania manažérov $\mathrm{v}$ tejto oblasti poskytnút' hotové odpovede a riešenia, ale je nutné pristupovat' $\mathrm{k}$ tomuto vzdelávaniu ako k prostriedku, ktorý sa stáva intelektuálnou investíciou, ktorú je potrebné v praxi tvorivo rozvinút'.

Uvedených autorov zaujímajú aj širšie sociálne súvislosti tejto problematiky, čoho odrazom je situovanie tejto etiky do všeobecnej etiky práce. Autori sa snažia zodpovedat' na otázku, za akých podmienok môže podnik pomôct' zamestnancom pri rozvíjaní ich osobnej etiky adekvátne $\mathrm{k}$ vlastným etickým perspektívam. V tejto súvislosti rozlišujú tri dimenzie etiky v situácii práce:

- vzt’ah k sebe samému (hodnotenie obsahu práce z pohl'adu osobnej dôstojnosti a úcty k sebe); 
- vzt'ah k iným (dôležitú úlohu tu pripisujú problému dôvery, ktorý sa premieta do spôsobu otvorenej komunikácie v spôsobe riadenia), pričom sa prikláňajú k Fukuyamovmu chápaniu dôvery ako centrálneho faktora pri rozvíjaní organizácií, kde dôvera sa stáva prostriedkom znižovania externalít v podobe nižších nákladov na kontrolu a znižovania rizika - $\mathrm{k}$ tejto rovine dôvery sa $\mathrm{v}$ našom článku ešte vrátime;

- vzt’ah k podniku ako k inštitúcii [tamže s.93].

Ďalšou prácou, na ktorú by sme chceli upozornit', je rozsahom menšia práca Fabienne Cardota L'éthique d'entreprise (2006), ktorá vytyčuje ako hlavný problém tejto etiky nezlučitel'nost' medzi dosahovaním zisku a morálnym úsilím a nasledovne problém hl'adania zosúladenia týchto dvoch dimenzií ekonomického života podniku. Predstavuje ju ako etiku zodpovednosti, ktorá riadi aktivity a správanie $\mathrm{v}$ pracovnej činnosti. „Etika podniku je etikou jednotlivcov ako zamestnancov $\mathrm{v}$ individuálnej aj kolektívnej rovine, a týka sa aktivít a správania v profesionálnej oblasti vo výrobe a službách [s. 7]. Je považovaná najmä za etiku pragmatickú, ktorá sa rozvíja predovšetkým v súvislosti s potrebou reagovania na nedostatky - ako sú chyby, škandály poburujúce verejnú mienku, ktoré škodia obchodným aktivitám podniku [tamže s.10]. Pre nás je podstatné, že okrem teoretickej roviny tejto problematiky je u tohto autora špecifické, že podčiarkuje predovšetkým kontextový charakter tejto etiky, ktorý je podl'a neho dôležitým aspektom vo svete, ktorý hl'adá svoje hodnoty. Táto kontextovost' obsahuje v jeho ponímaní predovšetkým nezmieritel'nost' s neutralitou, vyhýbaním sa riešeniu pálčivých problémov. Pre slovenské, ale určite aj české prostredie, by mala vyzniet' ako vel'mi aktuálna výzva, aby táto profesijná etika popri rešpektovaní ekonomických efektov podnikania $\mathrm{v}$ súlade $\mathrm{s}$ realizáciou princípu zodpovednosti globálnej etiky neustupovala strachu, l'ahostajnosti (laisser-faire), ale mala by aktívne vstupovat' do debaty pluralitnej spoločnosti [porovnaj tamže s. 15 - 16]. Táto výzva je naplnená existenciou rôznych francúzskych inštitúcií, ktoré sa touto rovinou sociálneho života aktívne zaoberajú a slovenské a české inštitúcie by sa mali čo od nich učit', najmä pri implementácii pestrejších nástrojov etiky do podnikania, ako sú len etické kódexy, ktoré často zostávajú len na formálnej úrovni (najmä v období hospodárskych turbulencií).

\section{Podniková kultúra a kultúra dôvery}

V rovine hodnotovej orientácie sa etická problematika ako súčast' podnikovej kultúry premieta do tzv. „etickej citlivosti“ organizácie, resp. firmy a vyjadruje vedomú reflexiu morálnych problémov podnikania. V tejto súvislosti vyvstáva otázka, aká organizačná štruktúra najviac vyhovuje etickým požiadavkám a zároveň, ktorá by otvárala priestor pre etickú reflexiu - etickú citlivost' organizácie.

Vytvorenie podmienok pre rozvoj etickej citlivosti organizácie vyžaduje takú organizačnú štruktúru, ktorá umožňuje získavanie informácií o eticky problémových situáciách a eticky problémovom správaní a vytvorenie priestoru pre diskurzívne riešenie týchto situácií. Musia byt' zlikvidované komunikačné bariéry a preto vzniká potreba budovania otvorených systémov komunikácie. Okrem toho je potrebné budovat' špeciálne štruktúry s etickým zameraním vo vnútri organizácie a zmenit' celkový charakter organizácie tak, aby bola otvorená pre etický postoj k problematike.

Za týmto účelom je potrebné, po prvé, formovat' špeciálne interné štruktúry ako súčast' implementácie etiky do podniku (etické kódexy, dôvernící pre etiku, horúce linky, vnútropodnikový systém pre vybavovanie st'ažností, oddelenie pre ochranu spotrebitel'ov, pracovníci zodpovední za image spoločnosti, oddelenia pre styk s verejnost'ou). Tieto súčasti organizačnej kultúry podniku prispevajú k inštitucionalizácii princípu dialógu. Uvedené 
funkcie by mali fungovat' ako partner pre interné či externé porozumenie v rámci konkrétneho podnikového správania. Prechádza na nich typická kompetencia dialógu v mene podniku, rozbiehajú v podniku proces argumentácie alebo naopak, obhajujú záujmy podniku voči kritikom. Pre budovanie etickej citlivosti organizácie je to však len prvý krok.

Po druhé, je d’alej potrebné budovat' takú organizačnú štruktúru, ktorá by smerovala k tomu, aby sa celková organizácia stala komunikačne schopnejšiou a pôsobivejšou. Opatrenia, ktoré by mali byt' v tejto súvislosti realizované, vyplývajú v zásade z revízie klasickej taylorovskej organizačnej štruktúry.

Nevyhnutnost' takejto zmeny orientácie vychádza z presvedčenia, že klasická pyramídová organizácia je vybudovaná s úmyslom, aby zabezpečila poriadok pri realizácii celkovej úlohy za predpokladu del'by práce. Zabezpečit' poriadok ale znamená výber alebo koncentráciu na dopredu dohodnuté pravidlá a tým súčasne zabránit’ kritickej reflexii. Organizácia znamená klasicky - prevedenie naplánovaného, a nie jeho kritické spochybnenie. Pokial' je tradičná organizácia založená na uzavretí problému, tak etika musí byt' oproti tomu vedúcou myšlienkou otvorenia problému. Etická citlivost' organizácie neznamená nič iné ako otvorenie zdedených tayloristicky uzatvorených pravidiel organizácie [pozri bližšie: Steinmann - Löhr 1995, s. 87].

V praxi to znamená orientáciu na skupinové procesy v rámci organizácie miesto zamerania na individuálne vzt’ahy, rovnako ako na správanie smerujúce na podporu predstavených miesto hierarchickej závislosti, d’alej na komunikačné spojenie naprieč hierarchiou namiesto hierarchicky spojených informačných kanálov, na delegovanie namiesto centralizácie rozhodovacích kompetencií, na uvol'nenie samokontroly namiesto vonkajšej kontroly a pod. Ide teda o budovanie „organizácie na základe dôvery“ namiesto tradičnej „organizácie na základe nedôvery.“

Kultúra dôvery je spojená s normami a hodnotami a zároveň s inštitúciami v rámci systému spoločnosti, ktoré ju môžu svojím fungovaním ovplyvnit'. Toto prepojenie môžeme vidiet' vo Fukuyamovom použití dôvery ako deliaceho kritéria pri analýze ekonomických systémov v rôznych krajinách. Fukuyama tvrdí, že existujú kultúry s vysokou mierou dôvery (high-trust cultures) [Fukuyama 1997, s. 77 an.] a kultúry s nízkou mierou dôvery (low-trust cultures) [tamže s.177 an.].

V dnešnom svete charakterizovanom existenciou dominantného ekonomického systému, tržnej ekonomiky, je výkonnost' určovaná predovšetkým schopnost'ou l'udí združovat' sa a spoločne (v organizáciách či skupinách) pracovat' pre spoločný ciel'. Taká spolupráca vyžaduje osvojenie si určitých noriem a hodnôt, medzi ktorými je vel'mi dôležitá dôvera. Spoločnosti, kde existuje vysoká dôvera, môžu významne ušetrit' na transakčných nákladoch. Naopak, spoločnosti, kde je dôvera nedostatočná, potrebujú pre svoje fungovanie detailné zmluvy a mnoho regulačných a kontrolných mechanizmov. Výkonnost' týchto ekonomík je nutne nižšia.

L. Mlčoch v svojej práci Ekonomie důvěry a společného dobra doporučuje uvažovat' o dôvere ako o súčasti kalkulovaného rizika. Pol'a tohto autora je najpravdepodobnejšia varianta zrodu a budovania dôvery v tejto oblasti v tzv. opakovaných hrách. Stratégia ,tit-for tat" (ako ty mne, tak ja tebe) dáva šancu na odštartovanie procesu posilňovania vzájomnej dôvery medzi partnermi. Tento proces je tiež procesom postupného budovania dobrej povesti či reputácie. Na vzniku ,goodwillu“, dobrom mene a na budovaní reputačného kapitálu, či už osobného alebo firmy, musí mat' záujem každý, komu ide o kontinuitu podnikania, kto hodlá podnikat' $\mathrm{v}$ dlhodobom časovom horizonte. Ide tu o výmenu zdania dôveryhodnosti za okamžitý zisk, kde sa platí cenou straty akéhokol'vek reputačného kapitálu. Toto bolo typické 
pre „podnikatel'ské“ aktivity v počiatkoch transformačného obdobia aj v našej spoločnosti. Takto je síce možné niekedy rýchle zbohatnút', nie však založit’ prosperujúci podnik.

Dôvera je zaradená medzi tzv. „neviditel’né aktíva“ (Kenneth Arrow), bez ktorého nemôžu určité zložitejšie typy transakcií v hospodárstve, a najmä vo svete financií vôbec vzniknút'. Existujú autori, ktorí fenomén dôvery považujú za predpoklad ekonomickej prosperity. Neexistencia dôvery a neustále porušovanie zmlúv a dohôd narúša základné predpoklady fungovania trhového mechanizmu, ktorý predpokladá konsenzus a chýbajúca dôvera zvyšuje transakčné náklady.

Ako je dôvera v praxi spojená s ekonomickými benefitmi ukazujú aj zistené súvislosti medzi ukazovatel'mi dôvery a elektronickým obchodom. Ten v porovnaní so Slovenskom, kde nákup cez internet tvorí len 3\% obchodného obratu, je ovel’a vyšší v Dánsku (20\%), ale tam je aj neporovnatel'ne vyššia dôvera obyvatel'ov v l'udí (66,5\%) ako na Slovensku. Tu len 15, $7 \%$ obyvatel'ov odpovedalo kladne na otázku, že väčšine l'udí možno dôverovat' [Jurzyca, 2009].

Dôvera vystupuje aj ako širší spoločenský fenomén, ktorým sa líšia jednotlivé kultúry, civilizácie a spoločnosti. Existuje už aj typ „etického auditu“ v medzinárodnom merítku, komparácia krajín, týkajúca sa cti a slušnosti partnerov, porovnávajú sa indexy korupčnosti verejnej a štátnej správy, ktoré odrážajú relatívnu nedôveryhodnost' byrokracie (rating a ratingové agentúry; audit a auditorské firmy; indexy vnímania korupcie - hodnotenie štátnej a verejnej správy; indexy hodnotenia prílišnej komplikovanosti, nejednoznačnosti a nevynútitel'nosti práva (tzv. opacity index).

Platí presvedčenie M. Novaka o tom, že kultúrne morálny systém slobodnej spoločnosti musí byt' posilnený, ak nemá trhová ekonomika a štátny a občiansky sektor trpiet'. Slobodná spoločnost' potrebuje viac cností, dodáva Mlčoch. Inštitucionalizovanú nezodpovednost' je potrebné začat' riešit' práve úsilím o zvýšenie morálky v spoločnosti.

Pre slovenskú realitu zrejme platí to isté konštatovanie ako aj v českej realite: nepodarilo sa ešte v našich spoločnostiach odštartovat' evolučný proces ,private ordering“, rast ducha kooperatívnosti, zodpovednosti, posilňovania dôvery a reputácie [porovnaj: Mlčoch 2006, s. 72].

Na vel'ké rezervy v tejto oblasti na Slovensku poukazujú aj sociologické výskumy, ktoré robila predovšetkým Remišová. Jej novší výskum z roku 2005, ktorý porovnával úroveň etických kódexov na Slovensku a v Nemecku potvrdil vo vzt’ahu k Slovensku pretrvavájúce problémy zistené v roku 1992. Analýza a porovnanie týchto etických kódexov jasne poukázala na to, že na Slovensku sa považuje za problém to, čo vo vyspelej ekonomike (ako je nemecká) sa považuje za samozrejmost'. Odráža to problematika etických okruhov, na ktoré sa tieto kódexy sústred’ujú. Základný rozdiel spočíva v tom, že v Nemecku sú etické požiadavky napríklad vo vzt'ahu $\mathrm{ku}$ stakeholderom orientované na menej skupín stakeholderov a vobsahu etických kódexov je zahrnutých menej okruhov s morálnymi záväzkami (Remišová konštatuje, že slovenské firmy majú celkovo väčšie množstvo morálnych problémov ako nemecké firmy). Kvalitatívna odlišnost' sa podl'a zistení tejto autorky prejavuje v tom, že slovenské firmy zretel'ne uprednostňujú etické okruhy spojené so vzt'ahmi a kvalitou medzil’udských vzt’ahov vo vnútri firmy, akými sú lojalita k firme, ochrana majetku a mena firmy a slovenské prostredie sa ešte potýka s eticky nevyhraneným vzt’ahom k súkromnému vlastníctvu. V západonemeckých fïmách dominujú etické okruhy späté s rešpektovaním legislatívneho, ekologického a sociálneho rámca, v ktorom firmy realizujú svoju podnikatel'skú činnost' [porovnaj: Remišová - Winkler, 2006]. Tietozávery jasne poukazujú na potrebu prekonávania formálnosti pri tvorbe etických kódexov a potrebu venovania väčšej pozornosti ich praktickej realizácii a funkčnosti v živote firiem, najmä 
s dôrazom na poznanie konkrétnych problémov. Ide hlavne o potrebu rozvíjania nástrojov spätnej väzby, ako sú linky dôvery, etický audit, dôverník pre etiku, ktoré vôbec nie sú samozrejmou súčast'ou riadenia.

Aktuálnost' hore uvedeného spoločenského fenoménu, akým je dôvera, vystupuje nástojčivo aj v rovine menej rozvinutej problematiky finančnej etiky, kde sa stáva súčast'ou insider trading, v ktorom ide o nákup či predaj cenných papierov, ktorý sa uskutočňuje na základe znalosti interných, neverejných či dôverných informácií. Táto činnost' sa považuje za neetickú a niektoré jej formy sú považované za nelegálne.

Ďalším vel'mi aktuálnym problémom sa stáva otázka prístupu k informáciám medzi obchodnými partnermi. Zákonne upravená povinnost' predajcov (Obchodný zákonník) ich zaväzuje neklamat' a nepodávat' zavádzajúce informácie o produktoch, resp. službách, ktoré ponúkajú a predávajú, nemajú však žiadnu povinnost' poskytnút' všetky informácie. Iná situácia nastáva tam, kde vzniká voči klientovi tzv. fiduciárna povinnost' (investičné poradenstvo a iné klientské vzt'ahy), kde zo zákona vyplýva povinnost' konat' v záujme svojich klientov. Reálne fungovanie týchto vzt’ahov na Slovensku aj v Čechách poukazuje na vel'ké rezervy $\mathrm{v}$ budovaní vzt'ahov dôvery $\mathrm{v}$ tejto rovine finančného podnikania. Ide totiž o vedomé prevzatie tejto zodpovednosti voči klientom, ktorý je napríklad formulovaný v etickom kódexe americkej spoločnosti CITI group tak, že spoločnost' koná vo fiduciárnej funkcii. To nás privádza $\mathrm{k}$ d’alšej rovine úvah v rámci etického uvažovania.

Pri rozvíjaní predpokladov manažéra pre typ podnikovej kultúry ako kultúry dôvery považuje autorka za potrebné chápat' manažérsku etiku a s ňou späté etické kompetencie ako dôležitú súčast' formovania manažérskych kompetencií ako súčasti profesionálnej výbavy manažéra.

\section{Morálka ako kompetencia}

Predpokladom pre to je chápanie samotnej morálky ako kompetencie, ktoré nachádzame u Kohlberga, a ktoré vyzdvihuje psychologickú rovinu morálky. Morálna kompetencia vyjadruje predovšetkým schopnost' robit' rozhodnutia a súdy, ktoré sú morálne (to znamená založené na vnútorných princípoch) a na ich základe konat' [Kohlberg, in Lind 2004 - podl'a: Ráczová, B. - Babinčák, 2009 s. 26]. Ako podstatná tu vystupuje súvislost', že aj ked' pojem morálnej kompetencie súvisí s morálnym usudzovaním, tak prostredníctvom rozvíjania morálnych kompetencií v tomto zmysle sa dostávame k dotváraniu takých osobnostných čŕt manažéra, ktoré súvisia s jeho charakterom. Takýto typ morálneho usudzovania je založený jednak na dodržiavaní pravidiel stanovených spoločnost’ou a zároveň sa opiera o vnútorné hodnoty jednotlivca - jeho vnútorné dispozície. Ide teda nielen o požadované správanie na základe spoločnost'ou požadovaných noriem, ale zároveň sa tu odrážajú jeho vnútorné hodnoty, princípy a motívy. Z psychologického pohl'adu, ako sa jednotliví autori odvolávajú na empirické výskumy, ani to však ešte nemusí viest' k morálnemu správaniu, pretože v realizácii, čiže v ,čine“- ešte zohráva úlohu množstvo d’alších podmieňujúcich faktorov [porovnaj: P.Lajčiaková 2005, s.17; Vacek 2008].

Dôležité ale je, že z tohto pohl'adu za morálne konanie možno považovat' konanie, ktoré korešponduje so všeobecne platnými morálnymi štandardami a súčasne s osobným morálnym presvedčením jednotlivca (pričom samozrejme môže nastat' situácia, ked' morálne presvedčenie jednotlivca sa nebude stotožňovat's morálnymi štandardami spoločnosti, ktoré nemusí byt' $\mathrm{v}$ súlade s princípmi etiky a humánnosti - D.N.). Vacek zároveň správne upozorňuje, že morálne presvedčenie smeruje k mravnému konaniu, iba ak má podporu v adekvátne rozvinutých vôl'ových a charakterových vlastnostiach (čestnost', zásadovost', ciel'avedomost', húževnatost', vytrvalost') [Vacek 2008, s. 63]. Morálne kompetencie 
predstavujú z psychologického hl'adiska most medzi morálnymi postojmi či morálnymi hodnotami na jednej strane a morálnym správaním na druhej strane. Morálne postoje predstavujú prevažne hodnotiaci vzt'ah, v ktorom sa odráža čiastočne rozumové poznanie, ale aj subjektívne emocionálne hodnotenie morálnych problémov [Lajčiaková]. Morálne kompetencie takto môžeme chápat' ako spôsobilost' jednotlivca dospiet' na základe svojich vnútorných zásad k morálnym úsudkom a následne konat' $\mathrm{v}$ súlade s týmito úsudkami. Morálne kompetentná osoba sa teda nielen morálne rozhoduje, ale aj morálne koná. Jej morálne zmýšl’anie sa odrazí v jej následnom morálnom správaní.

Za morálne konanie sa všeobecne považuje konanie v súlade s mravnými normami a hodnotami. Predstavuje to, čo skutočne robíme, ako sa prezentujeme navonok. Ale medzi morálnym konaním a morálnym myslením nemusí byt' vždy súlad. Morálne konanie je ovplyvnené jednak úrovňou morálneho usudzovania, jednak situačnými faktormi. „Morálne myslenie (morálne usudzovanie) zahŕňa jednak znalost' morálnych noriem, ako i spôsob uvažovania o morálnych problémoch - spôsob ako jednotlivec vníma morálne problémy a pokúša sa ich riešit'“[Lajčiaková 2008, s.17].

V takomto ponímaní je morálnost' vyjadrená ako schopnost', kompetencia (nielen ako názor, hodnota, ideál), čím sa prekonáva rozdelenie medzi emočnou, kognitívnou a konatívnou zložkou morálky. Význam tohto chápania morálky ako kompetencie podl'a Lajčiakovej spočíva v tom, že morálnost' bola definovaná vo vzt’ahu k vnútorným, prijatým morálnym princípom jednotlivca, nielen $\mathrm{v}$ relácii k externým sociálnym normám a štandardom - to sa skôr označuje za konformnost' (ako snaha vyhoviet' spoločenským normám a pravidlám). Z psychologického hl'adiska (Lind 1997) morálnost' musí byt' vyjadrená predovšetkým prostredníctvom pojmov opisujúcich vnútorné stavy, až následne môžeme opisovat' vonkajšie správanie jednotlivca. Z toho potom vyplýva, že ,správanie označujem ako morálne len v tom prípade, ak osoba koná v súlade s vlastnými morálnymi princípmi a zásadami“ [Lajčiaková s.67]. Samozrejme, tieto vnútorné morálne zásady a princípy musia byt' v súlade zo základnými zásadami humánnosti a etiky.

V problematike morálnych kompetencií sa špecifickým spôsobom odráža podstatný, psychologický aspekt morálneho konania, ktorý zohráva dôležitú úlohu aj v profesionálnej oblasti, pretože aj tu motívom konania môžu byt' často hlboko osobné, resp. vnútorné dôvody. Účinný morálny apel na človeka musí vychádzat' predovšetkým z pochopenia psychologických čŕt a náklonností osobnosti, pretože len väčšie rešpektovanie významu vnútorných hodnôt, princípov a motívov a vnútorných dispozícií jednotlivca nám umožní prihliadat' k psychickým, charakterovým a vôl'ovým vlastnostiam konajúceho.

\section{Záver}

Ciel'om nášho príspevku bolo poukázat' a vyzdvihnút' tie základné a aktuálne súvislosti, ktoré podčiarkujú potrebu implementácie etiky do manažérskej práce, ktorá najmä v čase súčasnej hospodárskej krízy nemusí byt' považovaná za samozrejmost'. Záverom môžeme pripomenút' aj aktuálnost' myšlienky T. Bat'u, ktorý za dôležitú súčast' hospodárskej krízy považoval mravnú biedu spoločnosti a preto ako dôležitú podmienku jej prekonania videl v obnovení mravného stanoviska kl’ud’om, k práci, verejnému majetku a znovuobnovenie dôvery v spoločnosti.

Autorka je zároveň presvedčená, že tvorivé zvládnutie implementácie etiky do podnikovej kultúry sa nezaobíde bez osobného angažovania manažérov, ktorí musia byt' presvedčení o význame etických nástrojov pri riadení firmy (morálka ako kompetencia so svojim sociálne - psychologickým rozmerom). K formovaniu ich etických kompetencií môže prispiet' 
praktická realizácia výučby manažérskej etiky v podobe prípadových štúdií, kde základom prípadovej štúdie sa stáva identifikácia etického problému v manažérskej praxi, rozbor konkrétnej etickej dilemy v aplikácii na konkrétne podmienky podnikatel'ského prostredia.

\section{Literatúra:}

[1] CARDOT, F.: L'éthique d'entreprise. 1. vyd. Paris: Universitaires de France, 2006, 352 s. ISBN 2-8041-2617-X

[2] DYTRT, Z. a kol.: Etika v podnikatelském prostředí. 1. vyd. Praha: Grada, 2006, 196 s. ISBN 80-247-1589-9

[3] FUKUYMA, F.: Zaufanie. Kapital społeczny a droga do dobrobytu. 1. vyd. Warszawa: WN PWN, 1997, 432 s. ISBN 83-01-12488-1

[4] LAJČIAKOVÁ, P.: Psychológia morálky. 1. vyd. Brno: CERM, 2008, 92 s. ISBN 97880-7204-569-3

[5] JURZYCA, E.: Kol'ko to stojí, ked' si l'udia neveria. In: SME, 6.12.2009

[6] MLČOCH, L.: Ekonomie důvěry a společného dobra. 1. vyd. Praha: Karolinum, 2006, 195 s. ISBN 80-246-1188-0

[7] NAVRÁTILOVÁ, D.: Premeny etiky a morálky v technologickom veku (Konanie a zodpovednost' ako zmysel (nielen) aplikovanej etiky). 1. vyd. Prešov: FVT TU, 2008, 111s. ISBN 978-80-553-0054-2

[8] NOVAK, M.: Filosofie svobody. 1. vyd. Praha: Vyšehrad, 1998, 240 s. ISBN 80-7021264-0

[9] ORLÉAN, A.: La confiance: un concept économique? In: Problèmes économiques, 3 mai 1995, s.7 - 14

[10] PESQUEUX, Y. - BIEFNOT, Y.: L'éthique des affaires. Management par les valeurs et responsabilité sociale. 1. vyd. Paris: Edition d'Organisation, 2002, 239 s. ISBN 27081-2816-7

[11] QUERE, L.: La structure cognitive et normative de la confiance. In: Réseaux 2001/4 $\mathrm{n}^{\circ} 108$ p. $125-152$ podl'a: www.cairn.info/article

[12] RÁCZOVÁ, B. - BABINČÁK, P.: Základy psychológie morálky. 1. vyd. Košice: UPJŠ, 2009, 130 s. ISBN 978-80-7097-786-6

[13] REMIŠOVÁ, A.: Etické kódexy. 1. vyd. Bratislava: Ekonóm, 1998, 128 s. ISBN 80225-0952-3

[14] REMIŠOVÁ, A. - WINKLER, I.: Komparácia firemných etických kódexov $v$ slovenských a západonemeckých firmách. In: Ekonomický časopis, 54, 2006, č. 6, s. $597-610$

[15] ROUX, M.: Finance éthique. Revue Banque, 2005

[16] STEINMANN, M. - LÖHR, A.: Základy podnikové etiky. 1. vyd. Praha: Victoria Publishing, 1995, 133 s. ISBN 80-85865-56-4

[17] VACEK, P.: Rozvoj morálního vědomí žáků. 1. vyd. Praha: PORTÁL, 2008, 128 s. ISBN 978-80-7367-386-4

[18] www.citigroup.com/citi/corporategovernance/codeconduct.htm

\section{JEL A1 A13}

\section{PhDr. Daniela Navrátilová, CSc.}

Katedra humanitných vied, vedúca katedry

Fakulta výrobných technológií TU Košice so sídlom v Prešove

Bayerova 1

08001 Prešov, SR

daniela.navratilova@tuke.sk 